\title{
THE ROLE OF PARTNERSHIP IN VALUE CHAIN OF SWEET POTATO IN REGENCY OF WEST JAVA (CASE STUDY OF PT GALIH ESTETIKA INDONESIA PARTNERSHIP)
}

\author{
Eva Farichatul Aeni*), Amzul Rifin ${ }^{* *}$, and Netti Tinaprilla**) \\ *) Agribusiness Study Program, Graduate School, Bogor Agricultural University \\ Jl. Raya Dramaga, Graduate School Building IPB, Dramaga Campus IPB 16680 \\ **) Department of Agribusiness, Faculty of Economics and Management, Bogor Agricultural University \\ Jl. Kamper Wing 2 Level 5, Dramaga Campus IPB 16680
}

\begin{abstract}
The partnership between the farmers and PT Galih Estetika Indonesia as the exporter company in the field of sweet potato processing is expected to support the development of sweet potato agribusiness in Kuningan Regency and become one of the solutions for farmers' problems. Termination of partnership contracts undertaken by the farmers will have an impact on the implementation of partnerships, company operations as well as the value chain. This study aims to analyze the pattern of partnership, degree of partnership, value chain structure, value chain governance, farmers' income (partner and non-partner) and margin. The method of data processing and data analysis used the descriptive analysis qualitative and quantitative descriptive analysis. The results showed that the pattern of partnership that is formed is a centralized pattern with the degree value of partnership of 716 (madya pattern). The structure of the value chain by mapping the actors and their activities result in relationships and coordination between the parties. Farmers with companies belong to the modular type in VCG. Economic benefits indicate that net income of partner farmers is Rp22,157,828/Ha, while non-partner farmers obtain Rp12,306,789/ $\mathrm{Ha}$ and the smallest margin is obtained by the coordinator. The analysis shows that farmers' incomes are larger, but partnership planning has not been ideal. Therefore, the roles of farmers, companies and related agencies are required in the running of the ideal sweet potato partnership program.
\end{abstract}

Keywords: sweet potato partnership, partnership pattern, value chain, value chain governance, revenue

Abstrak: Kemitraan antara petani dengan PT Galih Estetika Indonesia sebagai perusahaan eksportir di bidang pengolahan ubi jalar, diharapkan mampu mendukung pengembangan agribisnis ubi jalar di Kabupaten Kuningan dan menjadi salah satu solusi bagi permasalahan petani. Pemutusan kontrak kemitraan yang dilakukan petani akan berdampak kepada pelaksanaan kemitraan, operasional perusahaan sekaligus berpengaruh dalam rantai nilai. Penelitian ini bertujuan menganalisis pola kemitraan, derajat kemitraan, struktur rantai nilai, value chain governance, pendapatan petani (mitra dan non mitra) dan marjin. Metode pengolahan data dan analisis data menggunakan analisis deskriptif kualitatif dan kuantitatif. Hasil penelitian menunjukan bahwa pola kemitraan yang terbentuk yaitu pola terpusat dengan nilai derajat kemitraan sebesar 716 (pola madya). Struktur rantai nilai dengan memetakan pelaku dan aktifitasnya yang menghasilkan hubungan dan koordinasi diantara pihak. Petani dengan perusahaan termasuk ke dalam tipe modular dalam VCG. Manfaat ekonomi menunjukkan bahwa pendapatan bersih petani mitra Rp22.157.828/Ha, sedangkan petani non mitra Rp12.306.789/ Ha. Sedangkan untuk marjin terkecil diperoleh koordinator. Analisis menunjukkan bahwa pendapatan petani mitra lebih besar namun perencanaan kemitraan belum ideal. Oleh karena itu, peran petani, perusahaan maupun dinas terkait sangat diperlukan dalam berjalannya program kemitraan ubi jalar yang ideal.

Kata kunci: kemitraan ubi jalar, pola kemitraan, rantai nilai, value chain governance, pendapatan

\footnotetext{
${ }^{1}$ Corresponding author:

Email: evafarichatulaeni@yahoo.com
} 


\section{INTRODUCTION}

Partnership is one of the institutions in the form of cooperation conducted between two or more parties within a certain period of time to achieve mutual benefits with the principle of mutual need and mutual benefit as agreed (Hafsah, 2000). Partnerships in agriculture are very important because of the condition of agriculture that still faces the problems experienced by the farmers such as limited capital, small land tenure and simple technology. In addition, the current agribusiness structure is still less systemic from upstream to downstream. From that point of view, there is a need for cooperation to complement the existing limitations through partnerships so that it can support the welfare of farmers

Partnerships in sweet potatoes as agricultural products in the field of food have been conducted, and indeed they need to be conducted because the sweet potatoes have a bright potential and prospect if driven by the institution through partnership cooperation. The perceived benefit is that it can create relationships between the partnering parties so that they will give impacts on the quantity and quality of sweet potatoes. However, in reality, sweet potato partnership program still needs to be improved either from partnership management or from human resources. The problem is as in the study in Jayawijaya Papua by (UNDP, 2004) that there is an unavailability of a special institutional forum which is organized professionally for sweet potato growers and does not have a continuous working pattern. In addition, partner offenses that would harm and affect the contract formed still occur.

Kuningan regency, West Java has been able to develop a region with a sweet potato processing company that is PT Galih Estetika. The company was established in 1993 as a processing company and exporter of sweet potatoes oriented to Japan and Korea markets. The company had seen the opportunities and potential of sweet potatoes in Kuningan Regency as the largest production center of sweet potatoes in West Java of 111,918 tons/Ha in 2012 and 118,884 tons/Ha in 2013 (Distankan Kuningan, 2014 ).

The existence of sweet potato processing industry encourages cooperation with farmers through partnership. The partnership between farmers and processing companies is expected to support the development of sweet potato agribusiness in Kuningan Regency and overcome the problems faced by the farmers such as the difficulty in business development due to limited capital, knowledge, and simple technology. This is because the company as the owner of capital has a stronger management, so it is expected to be one solution to the problems that are still faced by farmers.

The existence of large amount of production and the occurrence of increased production attract attentions and it is expected to realize the expectations of the Agriculture Office of Kuningan Regency to continue producing sweet potatoes a commodity and can compete in the market in the country and abroad. However, to achieve this requires an inclusive growth. Daryanto (2009), explains that inclusive growth is growth that not only benefits big business actors but also increases the participation of small business actors i.e. farmers.

Farmers are the main producers that have an important role in the cultivation and sustainability of sweet potato production. This important role should be balanced by increasing the value or welfare of farmers as farmers' incentives, in order for farmers to remain sustainable in sweet potato cultivation. Incentives are given in the form of institutional forums through partnerships. The incentive is needed because the condition of sweet potato growers in Kuningan Regency is still dominated by small scale farmers, has a weak bargaining position, limited capital and low knowledge especially in market network.

The partnership between farmers and PT Galih Estetika was established in 1997 because the company needed continuity of raw material of sweet potato, while farmers needed market guarantee, stable price and facilitation in obtaining seeds. However, in the implementation, the farmers broke the partnership contract with PT Galih Estetika. The contract termination was seen in 2011, and the percentage of farmers who made the contract with the company reached $80 \%$, but in Year 2016 to, it decreased by $30 \%$. Termination of the contract was assumed to affect the performance of partnerships, company operations, as well as value chain such as the difficulty in obtaining raw material supplies that cannot meet consumer demands. Also it affects human resources, production and other matters related to the company's operations. 
Therefore, based on the above explanation, it is required to have a role of partnership in the value chain of Sweet Potatoes. Trienekens (2011) argues that partnership is part of upgrading value chain, and this partnership is one strategy that can be done to improve the value chain with vertical and horizontal relationships. Based on the previous research by Risenasari (2013), the role of partnership on the formation of the marketing chain is to shorten the marketing chain, so that the number of marketing institutions involved in the marketing chain is reduced, especially the number of brokers that results in low margin. In addition, the partner farmers earn better revenue that the non-partners. This is because partnerships relates to stakeholders as the producers of raw materials, sweet potato growers, traders on a small scale, small and medium enterprises that lead to changes in the performance of the value chain. In line with this, it is expected that by establishing a partnership, it can provide technical and economic benefits. Therefore, this study aims to analyze the pattern of partnership and levels of sweet potato growers with PT Galih Estetika in Kuningan regency, West Java, to analyze the value chain of sweet potato in PT Galih Estetika, Kuningan Regency, West Java; and to analyze the role of partnerships in the sweet potato value chain at PT Galih Estetika, Kuningan Regency, West Java.

\section{METHODS}

The data used in this research were primary data with observations and interviews through a questionnaire, while the secondary data came from institutions related to the research object (PT Galih Estetika Indonesia, Agriculture Service of Kuningan Regency).

The determination of respondents was done purposively, and as many as 30 people (farmer partners) were bound to have a contract with the company and 30 respondents (non-partner farmers) who sell their product to the company while 13 respondents were determined by the method of snowball sampling i.e. for marketing actors (collecting traders, coordinators and companies).

Method of data processing and data analysis used qualitative and quantitative descriptive analyses. Qualitative analysis (partnership pattern and degree of partnership) is to answer goal number 1, while value chain structure by mapping value chain and value chain governance is to answer goal number 2). Quantitative analysis (calculating the degree of partnership, income and margin) is to answer goal number 3 ).

\section{Patterns and Partnership Degrees}

The partnership pattern is to analyze partnership system between farmers and PT Galih Estetika in which there are rights and obligations of the partners. From this, it will show the pattern of partners formed by the farmers and company. The degree of partnership is to measure the level of partner relationship. Measurement of the degree of partnership by assessing the indicators of each aspect covering aspects of partnership management processes (planning, organizing and implementation and effectiveness of cooperation) and benefits (economic, technical and social) was perfomed. The indicators had a certain value that had been adjusted with the Decree of the Minister of Agriculture No. $944 / \mathrm{Kpts} /$ OT.210/10/97 dated October 13, 1997 on guidelines in establishing the level of partnership of agricultural business (Agribusiness Agency, Ministry of Agriculture, 1998). Measurement of the degree of partnership is in Table 1. The maximum and minimum values had been determined by the Ministry of Agriculture when conducting research on the partnership pattern. In his research, respondents chose one statement from the questionnaire, which had no value. The questionnaire included various revelations in the factors assessed.

\section{Value Chain Mapping}

ACIAR (2012) explains that the mapping stage in the value chain includes mapping the core processes of value chain activities, identifying and mapping the actors involved, mapping the specific activities undertaken by actors from the core process, mapping the flow of products, mapping the types of information flows, volume of the product, and mapping the number of offenders. This value chain mapping makes it easy to analyze the value chain

\section{Value Chain Governance (VCG)}

VCG is to see how the relationship and coordination between actors in the value chain works. Parameters were determined by analyzing the complexity of information and knowledge, ability to codify information and suppliers' ability to give respond, and then low or high category was given to each parameter. From this, the VCG types such as market, modular, 
relational, captive and hierarchy can be identified. If the relationship and coordination between the parties get stronger, the performance of the value chain gets better.

a. Market. It is defined that coordination is still low, so that each market has not been well coordinated.

b. Modular. it is defined that the coordination between suppliers and lead firms is still very small, resulting in a high ability of suppliers to provide the same information required by lead firms.

c. Relational. It is defined that there is coordination between the lead firm and the supplier that is characterized by a reciprocal information flow.

d. Captive. It is defined that the coordination between the lead firm and the supplier is high so that the supplier depends on the lead firm.

e. Hierarchy. It is defined that coordination between lead firm and supplier is very high. In this type, it can be said that suppliers are bound in an integrated company

\section{Revenue Analysis}

Farm income earned from farm revenues is reduced by farm expenditures. Revenue is the quantity of sweet potatoes sold and multiplied by the selling price whereas expenditure is expenses incurred by farmers in sweet potato cultivation. Mathematically, farm income is (Soekartawi et al. 2011):

$$
\Pi=\mathrm{Px} \times \mathrm{Y}-\mathrm{Bt}+\mathrm{Bd}
$$

Description: П (Farm Revenue (Rp)); Px (Sweet potato selling price $(\mathrm{Rp} / \mathrm{Kg})$ ); Y (Total quantity or quantity of sweet potato $(\mathrm{Kg})$ ); Bt (All cash costs incurred by farmers (Rp)); Bd (All calculated costs incurred by farmers (Rp))

\section{Margin Analysis}

Margin Analysis is used to identify the differences in prices at the farmer level with those at the consumer level. Therefore, the margin is the difference between the price paid by the consumer and the price paid by the farmer.

$$
\begin{gathered}
\mathrm{Mi}=\mathrm{Psi}-\mathrm{Pbi}(1) \\
\mathrm{Mi}=\mathrm{Ci}+\pi \mathrm{i}(2)
\end{gathered}
$$

From equations (1) and (2), it is obtained

$$
\mathrm{Psi}-\mathrm{Pbi}=\mathrm{Ci}+\pi \mathrm{i}
$$

Then the benefits of each actor is:

$$
\Pi=\text { Psi }- \text { Pbi- } \mathrm{Ci}
$$

\begin{tabular}{|c|c|c|c|}
\hline Aspect & Indicator & Assessed factor & Maximum factor value \\
\hline \multirow{6}{*}{$\begin{array}{l}\text { I. Partnership } \\
\text { Management } \\
\text { Process }\end{array}$} & \multirow[t]{2}{*}{ Planning } & a. Partnership Planning & 100 \\
\hline & & b. Planning Completeness & 50 \\
\hline & \multirow[t]{2}{*}{ Organizing } & a. Custom Field & 25 \\
\hline & & b. Cooperation Contract & 125 \\
\hline & \multirow{2}{*}{$\begin{array}{l}\text { Implementation and } \\
\text { effectiveness of cooperation }\end{array}$} & a. Partnership implementation & 50 \\
\hline & & b. Cooperation Effectiveness & 150 \\
\hline \multicolumn{3}{|c|}{ Maximum value of aspects of partnership management process } & 500 \\
\hline \multirow[t]{8}{*}{ II. Benefits } & \multirow[t]{4}{*}{ Economics } & a. Income & 100 \\
\hline & & b. Price & 100 \\
\hline & & c. Productivity & 50 \\
\hline & & d. Business Risk & 50 \\
\hline & \multirow[t]{2}{*}{ Technical } & a. Quality & 50 \\
\hline & & b. Technology Mastery & 50 \\
\hline & \multirow[t]{2}{*}{ Social } & a. Intention in Continuous Cooperation & 50 \\
\hline & & b. Environmental Conservation & 50 \\
\hline \multicolumn{3}{|c|}{ Maximum Value of Benefit Aspects } & 500 \\
\hline \multicolumn{3}{|l|}{ Total } & 1,000 \\
\hline
\end{tabular}

The total margin was obtained by adding the margin of each actor mathematically, so the total margin is as follows (Asmarantaka, 2012):

Table 1. Measurement of partnership degrees

Source: Agribusiness Agency Ministry of Agriculture (1998) in Pratiwi (2003). 


$$
M T=\sum_{1=1}^{n}(M i)
$$

Description: Mi (Number of sweet potato margin at the actor level $(\mathrm{Rp} / \mathrm{kg})$ ); Psi (sweet potato selling price on the i-th level $(\mathrm{Rp} / \mathrm{kg})$ ); Pbi (Price of sweet potato purchasing on the i-th level $(\mathrm{Rp} / \mathrm{kg}))$; $\mathrm{Ci}$ (TCost of sweet potato on the level-ith actor $(\mathrm{Rp} / \mathrm{kg})$ ); $\pi \mathrm{i}$ (Benefits of sweet potato at the i-th level $(\mathrm{Rp} / \mathrm{kg})$ ); MT (Total margin of sweet potato $(\mathrm{Rp} / \mathrm{kg})$ ).

\section{RESULTS}

\section{Partnership Pattern}

PT Galih Estetika Indonesia is a legal corporation established since 1997 with a limited liability company (PT) and engaged in the processing of sweet potato. The company is located in Bandorasa Village, Cilimus District, Kuningan Regency, West Java. Products produced are in the form of semi-processed products such as powder, pasta, and solid. The products are superior products of the company by taking raw materials from partner farmers or non-partners who come from Kuningan or outside Kuningan Regency. Semi-finished products are exported to Korea and Japan and are made into final products for sale to final consumers.

The thing behind the company to establish partners with farmers is that the company gets sustainable supply of sweet potatoes, and farmers get market guarantees and stable prices. Also, they obtain information in improving the quality of sweet potato and the welfare of farmers. Cooperation relationship between partner farmers and company includes the field of marketing, the field of cultivation and other assistance in the form of seeds, packaging (sack) and transportation.

\section{1) Cooperation in marketing}

The company purchased yield crop from partner farmers and non-farmers, and they are required to sell their products to the company with predetermined criteria. Partner farmers are farmers who have a contract with the company, whereas non-partner farmers are farmers who are not in the contract with the company. These criteria include seeds of varieties (AC, Bogor, Maja), sweet potatoes in fresh condition, no bruising, no diseases (lanas, rotten), based on the predetermined grades (grade $\mathrm{A}>200$ grams with a minimum diameter of $3 \mathrm{~cm}$, grade B 100- 200 gram with diameter of 2-3 $\mathrm{cm}$ and grade $\mathrm{C}$ that is $<100$ gram with diameter $<2$ ).

\section{2) Cooperation in the field of cultivation}

Cooperation in the field of cultivation encourages the farmers to participate in the determination of seed types, grading, size and other things that have been determined by the company. However, the agricultural input facility provided by the company is only seeds. For cultivation technique, the company lets each farmer to use their own because they are considered to be experienced. However, the company remains in charge of monitoring, giving counseling to farmers at least three times in 1 month if there is information on cultivation techniques. This is done by directly visiting the farmers and by providng what the farmers need. Guidance or counseling is conducted with the aim that farmers remain in the supervision of the company to maintain the quality of sweet potato. In addition, guidance in this case aims to succeed the joint program in achieving a sense of responsibility to seek the sustainability of cultivation.

The success of farmers on the task of the company in providing counseling in the field is reflected by large production yields with good quality, and they still continue the partnership. The sustainability of cooperation partnership is indirectly felt by the farmers since they get motivation to establish good relationships both in personal and trading relationships that end up in achieving mutual benefits.

Based on the results of the above explanation, it can be concluded that the partnership pattern formed between the partner farmers with the company of PT Galih Estetika Indonesia emplys the pattern of centralized partnership. In this partnership pattern, the buyer buys and processes the yields and markets the produced products. In this case, that the company buys sweet potatoes from the farmers, collecting traders and coordinators. Sweet potatoes will be processed by the company as semi-finished products and then marketed to its export destinations of Japan and Korea. This is consistent with that definition by Eaton $\mathrm{C}$ and Shepherd AW (2001). Sweet potato products are controlled by the company from the beginning stage of cultivation so that good quality and good standard of yields can be harvested. In this model, the buyer's involvement varies (in terms of product or input provision) starting 
from controling most aspects of production (controls production activities), providing coordination services between farmers and buyers in a strict and organized way (in terms of product quantity, quality, harvest), to harvesting.

Meanwhile, the pattern of partnership is based on the reference of the decision of the minister of agriculture No.940/Kpts/Ot.210/10/1997stating that the partnership pattern of the farmers with PT Galih Estetika Indonesia is the pattern of agribusiness operational cooperation (KOA). In this case, farmers provide land, labor, raw materials (fertilizers and medicines) and own capital. Hovewer, the company guarantees the product market by increasing the added value through processing. The company provides seedlings to the farmers, and they will pay the cost after harvest or their revenue will be cut in accordance with the number of seeds used. Provision of seeds is the facility given by the company in addition to post-harvest transportation.

\section{Degree of Partnership}

The results of the research are shown in Figure 1. The blue-marked aspect describes the process of partnership management, where the implementation and effectiveness of cooperation have the greatest value of 128 while the benefit aspect marked by green color shows that the economic indicator has the highest value of 217. Therefore, partnership has an income impact on partner farmers. However, when we viewed from the 2 aspects, the benefit aspect gave a greater value (415) if compared with the aspect of the partnership management process (352).
The factors that influence the partnership management in the planning include only marketing, technology assistanship, guidance and agricultural production facility. In the organization, that there is no specialized field from outside that handles the partnership; therefore, it relies solely on the division of the company whereas in the implementation and effectiveness of cooperation, there is still existence of contract agreement made orally. The contract poses quite a risk which results in low commitment. Examples of such impacts are farmers selling their crops outside their area if prices are more secure, while the company did not provide assertiveness to the given sanction. Sanctions are punishments that will be given to the actors. This means that the more firmly defined and implemented sanctions are, the more positive the actions caused by the fear that will arise to commit the offense. Similarly, the research by Stefanus et al. (2007) explained that the existence of sanctions is quite effective and deterrent.

Also, the long period of payment of the contract agreement makes the farmers to have low trust. The farmers have to wait for a long time for the payment because they have to wait for their products to be sold and also because of the rules of import and export. This is very important for the farmers, because the capital will be spent for daily life or for cultivation of sweet potato and other commodities. If the delay of payment is still conducted by the company, it will lead the farmers to search for outside markets despite their contract with the company.

Planning

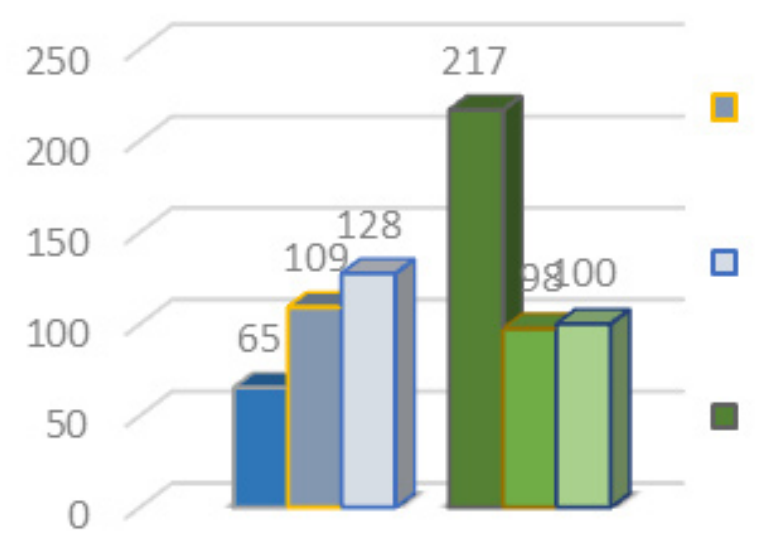

Organizing

Implementation and effectiveness of cooperation

Economics

Figure 1 Measurement of partnership degree 
Other things that result in a smaller degree value of partnership in the partnership management include the continuity of the sweet potato supply supplied by the farmers, the uncertain time of harvest by the company due to the uncertain time in the cultivation of sweet potatoes, and the farmers will be freed from the contract time. Meanwhile, if the company determines these, it will make the company's operations to be smooth, especially in terms of fulfillment of demand.

For the benefit of the economic aspect, the farmers perceive the benefits of the income generated. One benefit is that the farmers should maintain and improve their knowledge if the company provides new information either in terms of seeds or cultivation techniques. The company also provides information on how to utilize input costs to be efficient both from how to obtain inputs or how to use them.

If seen from the two aspects of partnership degree i.e. the partnership management process and benefits aspects, the farmers, in fact, earn a greater income. It shows that the assistance or extension program conducted by the company to the farmer especially on the information of sweet potato cultivation was well conveyed. The farmers already know the science of cultivation in the field, so the company lets farmers to work by themselves and provides information, guidance and direction to them.

\section{Value Chain Mapping}

Value chain mapping is used to describe and to identify the value chain pattern and activities undertaken by each actor in the sweet potato value chain at PT Galih Estetika Indonesia. This mapping makes it easy to analyze the value chain activities undertaken by the actors. These essential activities are basically aimed at creating and increasing value and competitive advantage for the company or the value chain actor.

ACIAR (2012) states the stages in value chain mapping including:

1. Mapping the core processes of value chain activities i.e. providing inputs/production facilities-cultivation activities (land-postharvest preparation), production of semi-finished products-export (intermediate products) and the end-consumer product processing company.

2. Identifying and mapping the actors involved and the specific activities undertaken by them.

\section{a. Input Provider Supplier}

This is the party that provides agricultural production facilities. In this case, it is the form of a store included into retail traders or wholesalers who market agricultural input products in kiosks scattered in several villages in Kuningan District, the place of the research. The products (saprodi) include fertilizers, agricultural equipment and medicines.

\section{b. Farmers}

The farmers are the party conducting sweet potato cultivation from the start of the land preparation to the post harvest (transporting sweet potatoes to be sent to the company or to the collecting merchant or to the Coordinator.

\section{c. Collectors Traders and Coordinators}

Collectors Traders are an important part in conveying information from the company to the farmers in marketing. They collect the sweet potatoes from the farmers and sell them to the company.

\section{d. Company PT Galih Estetika Indonesia}

PT Galih Estetika Indonesia is a sweet potato processing company in Kuningan Regency. The company plays a role in determining the requirements to the farmers as defined by the company (grading, seeds used and others related to the quality of sweet potato), purchasing sweet potatoes, processing sweet potato products, transporting and marketing the products.

\section{Mapping the product flow}

The products are started from sweet potato seeds that will produce fresh sweet potatoes, and then they are processed into semi-finished products by PT Galih Estetika Indonesia and exported to Japan and Korea as end products.

\section{Mapping the type of information flow}

The information flow is obtained from the exporter company regarding quality of sweet potato, harvest time, etc. inquired by the consumers, and it is then conveyed to the collecting trader/coordinator and finally to the farmers as the producers. 
5. Mapping the product volume and mapping the number of offenders.

According to the sweet potato channel, the distribution of sweet potato from the farmers to company is 280,689 $\mathrm{kg}$, farmers to the coordinator is $205,742 \mathrm{~kg}$, and farmer directly to the collecting trader is $394,899 \mathrm{~kg}$.

\section{Value Chain Governance}

Based on Gereffi et al. (2005), this research produced a type of relationship between two parties i.e. farmers and company belonging to the modular category. Collecting traders and the company are included in the market category. Coordinators and company are included in the relational category. Farmers and collecting traders are included in the market category and farmers and the Coordinator belongs to the relational category.

Overall, relationships among value chain actors are fairly coordinated if seen from the aspects of information complexity, uniformity and suppliers' ability to respond that is the relationship between the company and the coordinator. Coordinators are the company delegation outside the company in charge of providing information from the company to the farmers. Coordinators should give full confidence to the company, and vice versa. This is implemented to maintain the continuity of the following business.

However, Schipmann (2006) shows that more complex segment and market criteria to be addressed, the more complex the governance structure will be; thus requiring a stronger relationship. As in Kodigehalli's (2004) study, it is included in the market coordination category. This is due to the low complexity of information as well as low ability to codify information or to provide uniform information. As a result, information flow through extension or counseling does not reach the farmers.

\section{The Role of Partnerships in the Value Chain of Sweet Potatoes}

\section{Revenue of Sweet Potatoes}

Based on Table 2, the net income of smallholder farmers is greater than that of non-partner farmers, although farmers' farming costs are higher. This is due to the larger amount of production by the farmer partners while the number of pests that attack is less. Revenue is influenced by the high amount of production by the partner farmers of equal to $486,431 / \mathrm{Ha}$ (Grade $\mathrm{A}=$ $435,679 / \mathrm{Ha}$ and Grade $\mathrm{B}=50,751 / \mathrm{Ha})$ and with the average prices of Grade A and Grade B are Rp 3,407/ $\mathrm{kg}$ and $\mathrm{Rp} 933 / \mathrm{kg}$ respectively. Meanwhile, the price from the non-partner farmers is Rp402,042/Ha (Grade $\mathrm{A}=346,766 / \mathrm{Ha}$ and Grade $\mathrm{B}=55,276 / \mathrm{Ha}$ ) with an average price of Grade A of Rp3,203/kg and Grade $\mathrm{B}$ of Rp1,023/kg. The effect of this price is different because the sales channel is different that is the partner farmers sell directly to the company and through the coordinator of the company, while for the non-partner farmers, they sell their products through the collecting merchants.

Table 2. Analysis of incomes of partner farmers and non-partner farmers in Sweet potato farming in PT Galih Estetika Indonesia

\begin{tabular}{lcc}
\hline \multicolumn{1}{c}{ Description } & $\begin{array}{c}\text { Partners } \\
\text { Value (Rp / Ha) }\end{array}$ & $\begin{array}{c}\text { Non Partners } \\
\text { Value (Rp / Ha) }\end{array}$ \\
\hline Cash Revenue (A) & $50,111,296$ & $38,086,854$ \\
Calculated Revenue (B) & 151,287 & 111,367 \\
Total of Revenue (C) & $50,262,582$ & $38,198,221$ \\
Cash cost (D) & $19,434,833$ & $14,200,905$ \\
Calculated Cost (E) & $8,669,921$ & $11,690,527$ \\
Total Cost of Farming (F = D + E) & $28,104,754$ & $25,891,432$ \\
Cash Income (G = A-D) & $30,676,462$ & $23,885,949$ \\
Net Income (H = C-F) & $22,157,828$ & $12,306,789$ \\
R/C at Cash Cost (I = A / D) & 2.58 & 2.68 \\
R/C over Total Cost (J = C / F) & 1.79 & 1.48 \\
\hline
\end{tabular}


The large amount of production by the farmers involved in this research is related to the number of pests that attack the sweet potatoes. This is evident from the cash costs for medicines used by the farmers were less than those used by the non-partner farmers. The nonpartner farmers spent a greater cost to spray pests and diseases up to 5 times of spraying. According to the farming science of risks in the field of agribusiness, the excessive administration of pesticides or medicines for agricultural crops can decrease their production.

Another problem is the difference of labor wages between the partner farmers and the non-partner farmers. The latter earn lower wages than the former for both men and women, and that average wage depends on the area of the farmers. In Kuningan Regency, the wages start from Rp65,000 to Rp90,000 and from Rp50,000 to $\mathrm{Rp} 80,000$ for men and women respectively. Therefore, from the results of quantitative calculations, the labor cost of the non-partner farmers is smaller compared to that of the partner farmers.

Total revenue is the revenue generated from the total amount of sweet potatoes sold, while the revenue is the amount of sweet potatoes for consumption and seeds.

\section{Margin Analysis}

Based on Table 3, there are three channels employed by the company. Channels I and II are channels for partner farmers in which they directly sell their products to the company and to the coordinator before reaching to the company. Channel II is channel of non-partner farmers who sell their products through the collecting merchants before reaching the company. All of these channels are channels based the company goals.

Based on the table, the margins in each channel vary, and this is influenced by the purchase price, selling price, costs and profits earned. Differences in prices received by farmers depend on price negotiations and the actors that become the goal of selling by the farmers. The actor has a strategy that has been considered before and is based on market conditions and costs incurred.

The smallest margin is obtained by the coordinator on channel II. The coordinator spends the least marketing cost compared to other actors that is $\mathrm{Rp} 113 / \mathrm{Kg}$ while the collecting trader spends Rp231/Kg. Small margin is also affected by the cost and purchase price of the company that is $\mathrm{Rp} 3,500 / \mathrm{Kg}$ while the collecting trader has a purchase price from the company of Rp3,550/Kg and the selling price of Rp3,203/Kg.

Table 3. Analysis of marketing margins of sweet potato value chain in PT Galih Estetika Indonesia

\begin{tabular}{lcccccc}
\hline \multirow{2}{*}{ Description } & \multicolumn{9}{c}{ Channels } \\
\cline { 2 - 7 } & \multicolumn{2}{c}{ Chanel I } & \multicolumn{2}{c}{ Chanel II } & \multicolumn{2}{c}{ Chanel III } \\
\cline { 2 - 7 } Farmers' & & & & & & \\
Selling price & 3,511 & 956 & 3,250 & 908 & 3,203 & 1,023 \\
Middlemen & & & & & & \\
Purchase price & - & - & - & - & 3,203 & 1,023 \\
Marketing Cost & - & - & - & - & 231 & 231 \\
Profits & - & - & - & - & 116 & -54 \\
Margin & - & - & - & - & 347 & 177 \\
Selling price & - & - & - & - & 3,550 & 1,200 \\
Coordinator & - & - & 3,250 & 908 & - & - \\
Purchase price & - & - & 113 & 113 & - & - \\
Marketing Cost & - & - & 137 & 180 & - & - \\
Profits & - & - & 250 & 292 & - & - \\
Margin & - & - & 3,500 & 1,250 & - & - \\
Selling price & & & & & & \\
Company & 3,511 & - & 3,500 & - & 3,550 & - \\
Purchase price & 107 & 107 & 107 & 107 & 8 & 8 \\
Marketing Cost & & & & & & \\
\hline
\end{tabular}




\section{Managerial Implications}

The results of the research from the three objectives stated show that partnerships have an effect on their role on the value chain. Therefore, the performance of the good value chain must optimized by balancing it with the existing partnership program and by achieving a win-win solution to give benefit for both parties. This will form the Value Chain Governance type based on coordination, information and cooperation that have been established. Ideal partnerships can certainly provide both technical and economic benefits (income). So the improvement of the partnership program must be continuously improved in accordance with the applied cooperation contract.

\section{CONCLUSIONS AND RECOMMENDATIONS}

\section{Conclusions}

The partnership of PT Galih Estetika plays a role in the company's sweet potato value chain. This is seen in the partnership pattern that is included in the KOA pattern and the value of the partnership degree reaches 716 (madya pattern). The value cannot be said to be an ideal partnership because it is influenced by several factors such as the timing of payments that are not in accordance with the contract, farmers who are still violating the rules, and the existence of the contract made orally

Implementation of partnerships that have not been ideal affects the value chain, especially partnership as a priority in obtaining sweet potato supply and becomes one of the determinants in the value chain of sweet potato. Other things affecting the company's operations include internal management of the company (number of labor, production time, and decrease of consumer demand fulfillment).

The existence of partnership; on the other hand, can increase the farmers' income to become larger (Rp22,157,828/Ha) than that of the non-partner farmers (Rp12,306,789/Ha). There are other positive benefits i.e. partnerships assist in shortening marketing channels and improving the flow of information more well coordinated (Channel I), thus resulting in low margin.

\section{Recommendations}

Based on the research results, some suggestions can be recommended. Farmers should be committed when they agree to partner and the company provides assertiveness in accordance with the contract agreement. The company also seeks to restore confidence to farmers about the on time payment system and not only market and price guarantees but also other production input facilities. In addition, the Kuningan District Agriculture Office coordinates with extension agents and companies to integrate sweet potato agribusiness.

\section{REFERENCES}

[ACIAR] Australian Centre for International Agricultural Research. 2012. Membuat Rantai Nilai Lebih Berpihak Kepada Kaum Miskin. Canbera: Australian Centre for International Agricultural Research

Asmarantaka RW. 2012. Pemasaran Agribisnis (Agrimarketing). Bogor: Departemen Agribisnis FEM-IPB.

[Distankan] Dinas Pertanian, Peternakan dan Perikanan Kabupaten Kuningan. 2014. Produksi tanaman pangan Kabupaten Kuningan tahun 2012-2013. Kuningan: Dinas Pertanian, Peternakan dan Perikanan Kabupaten Kuningan.

Daryanto A. 2009. Kemitraan dalam Manajemen Rantai Nilai Bisnis Peternakan. Trobos. Rubrik Opini.

Eaton C, Shepherd AW. 2001. Contract Farming Partnership for Growth. FAO Agriculture Organization Services Buletin 145.

Gereffi G, Humphrey J, Sturgeon T. 2005. The governance of global value chain. Review of International Political Economy 12(1): 78-104. https://doi.org/10.1080/09692290500049805.

Hafsah JM. 2000. Kemitraan Usaha, Konsep dan Strategi. Jakarta: PT Penebar Swadaya.

Kodigehalli. 2004. Value chain analysis for coffe in Karnataka, India [thesis]. Jerman: University ff Berlin.

Risenasari H. 2013. Analisis peranan kemittraan terhadap rantai nilai sapi potong peternakan rakyat di Kabupaten Banjarnegara, Provinsi Jawa Tengah [tesis]. Bogor: Institut Pertanian Bogor. 
Schipmann.2006. Value chains for a better integration of smallholders to trader-the case of Chili in Ghana [thesis]. Berlin: Departement of Agricultural Economics and Social

Soekartawi A, Soeharjo, Dillon JL, Hardaker JB. 2011. Ilmu Usahatani dan Penelitian untuk Pengembangan Petani Kecil. Jakarta: Universitas Indonesia Press.

Stefanus S, Supriharyono, Bambang AN. 2007. Pengelolaan sumberdaya pesisir dan laut melalui pemberdayaan kearifan lokal di Kabupaten
Lembata Propinsi Nusa Tenggara Timur. Jurnal Pasir Laut 2(2): 67-82.

Trienekens J. 2011. Agriculture value chain in developing countries a framework for analysis. International Food and Agribusiness Management Review 14 (2): 51-82.

[UNDP] United Nations Development Programme. 2014. Kajian Ubi Jalar dengan Pendekatan Rantai Nilai dan Iklim Usaha di Kabupaten Jayawijaya. Papua: United Nations Development Programme. 